\title{
School Type and Mathematics Achievement in English-Speaking Primary Schools in Cameroon: Implications for Technological Development
}

\author{
Endeley Margaret Nalova* \\ Department of Curriculum Studies and Teaching, Faculty of Education, University of Buea, Cameroon \\ *Corresponding author: endeleynalova@yahoo.com
}

\begin{abstract}
Science and Technology are critical for propelling Cameroon towards emergence and primary school mathematics creates a good foundation for Science and Technology. However, very little research in Cameroon has focused on assessing mathematics achievement in primary schools in order to forecast the future of Science and Technology. The study thus set out to assess the mathematic achievement of class six (final year) pupils in 18 English-speaking public, private and confessional primary schools in six divisions of the North West and South West regions of Cameroon. An achievement test which is an extract of the 2013/2014 First School Leaving Certificate Examination constituted the instrument for data collection. Thus validity and Reliability had already been established by the Ministry of Basic Education. Data were analyzed descriptively and inferentially. Results revealed that mathematics achievement is generally low and differs by school type. Implications and recommendations are discussed.
\end{abstract}

Keywords: numeracy, mathematics achievement, technological development, primary schools, Cameroon

Cite This Article: Endeley Margaret Nalova, "School Type and Mathematics Achievement in English-Speaking Primary Schools in Cameroon: Implications for Technological Development." American Journal of Educational Research, vol. 5, no. 5 (2017): 568-573. doi: 10.12691/education-5-5-15.

\section{Introduction}

Cameroon aims at achieving emergence by 2035 by alleviating poverty and becoming a middle income country. Numeracy is critical in attaining this goal. Numeracy may signify any one of a number of things including, basic computational arithmetic, essential mathematics, social mathematics, survival skills for everyday life, quantitative literacy, mathematical literacy and an aspect of mathematical power [34]. Numeracy is closely related to mathematics. Without a solid grounding in mathematical concepts and procedures, there can be no numeracy. Mathematics is important in our everyday life, allowing us to make sense of the world around us and to manage our lives. Using mathematics enables us to model real life situations and make connections and informed predictions. It equips us with the skills we need to interpret and analyse information, simplify and solve problems, assess risk and make informed decisions. To face the challenges of the 21st century and each young person needs to have confidence in using mathematical skills [13].

The economic benefits of numeracy are enormous. There is a positive relationship between numeracy skills and earnings [19,28]. Apart from demands of modern workplaces, and raising the overall skill levels of the workforce, there are also social benefits tied to improving access for larger numbers of young people to post-school education and training opportunities and laying stronger foundations to skills for lifelong learning [24].

Numeracy lays a good foundation for mathematical sciences. The discipline known as the mathematical sciences encompasses core (or pure) and applied mathematics, plus statistics and operations research, and extends to highly mathematical areas of other fields such as theoretical computer science. An important characteristic of the mathematical sciences is that they overlap with many other disciplines of science, engineering, and medicine, and, increasingly, with areas of business such as finance and marketing. So much of science and engineering now builds on computation and simulation for which the mathematical sciences are the natural language. In addition, data-collection capabilities have expanded enormously and continue to do so, and the mathematical sciences are innately involved in distilling knowledge from all those data [43]. The importance of such a discipline for a developing country like Cameroon, aiming to attain emergence cannot be over emphasized.

The Primary School Curriculum plays a key role in preparing children to meet the demands of the 21stCentury. It prepares children to think and communicate quantitatively and to use mathematics to solve problems [22]. This study, thus aims at assessing the achievement in mathematics in English-speaking primary schools in Cameroon and the extent to which the achievements differ by school type in order to determine the country's future in Science and Technology which are critical in the attainment of emergence. 


\section{Review of Literature}

\subsection{Relationship between Mathematics and Science and Technology}

Fox [18] asserts that young children are being born into a world that is built on digital technology - a world where having competence and the disposition to use mathematics in context is essential. Considering the widespread demand for a numerate citizenry in a digital age, it is essential that young children develop the foundations of digital numeracy. Fox argues that the skills, knowledge, and abilities needed to participate and succeed in the $21^{\text {st }}$ century society are vastly different to those needed in the previous century. The amplified need for numeracy is a result of the demands of the technologically oriented age [32]. Steen [41] credits the rise in quantitative data, numbers, and information to the universal increase in the usage of technology, computers, and the internet. Mathematics has played and continues to play a critical role in expanding fields of science and technology because of the basic requirement that research needs to be able to quantify and accurately evaluate the results of changes/advances in a field of endeavor.

The Science of All Americans [39] outlines the relationship between science and mathematics. Science provides mathematics with interesting problems to investigate, and mathematics provides science with powerful tools to use in analyzing data. Often, abstract patterns that have been studied for their own sake by mathematicians have turned out much later to be very useful in science. Science and mathematics are both trying to discover general patterns and relationships, and in this sense they are part of the same endeavor. Also, mathematics is the chief language of science. The symbolic language of mathematics has turned out to be extremely valuable for expressing scientific ideas unambiguously. More importantly, mathematics provides the grammar of science-the rules for analyzing scientific ideas and data rigorously.

Mathematics and technology have developed a fruitful relationship with each other. The mathematics of connections and logical chains, for example, has contributed greatly to the design of computer hardware and programming techniques. Mathematics also contributes more generally to engineering, as in describing complex systems whose behavior can then be simulated by computer. In those simulations, design features and operating conditions can be varied as a means of finding optimum designs. For its part, computer technology has opened up whole new areas in mathematics, even in the very nature of proof, and it also continues to help solve previously daunting problems.

Wright and Chorin [44] assert that Mathematics and science have a long and close relationship that is of crucial and growing importance for both. Mathematics is an intrinsic component of science, part of its fabric, its universal language and indispensable source of intellectual tools. Reciprocally, science inspires and stimulates mathematics, posing new questions, engendering new ways of thinking, and ultimately conditioning the value system of mathematics. Fields such as physics and electrical engineering that have always been mathematical are becoming even more so. Outside the traditional spheres of science and engineering, mathematics is being called upon to analyze and solve a widening array of problems in communication, finance, manufacturing, and business. Progress in science, in all its branches, requires close involvement and strengthening of the mathematical enterprise; new science and new mathematics go hand in hand. As a result, Daugherty, Reese, and Chris Merrill (n.d) posit that many reports have called for better preparation in mathematics and science, and for increased skills for the technology-rich work-place of the 21st century $[3,6,31,33]$.

\subsection{School Type and Achievement in Mathematics}

Proponents of school choice and school reform often claim that different school "types" will produce better academic outcomes for students than does the traditional public school model. Unstated but implicit in these views is a causal assumption that certain school types are better and produce improved student academic achievement [14].

Lubienski, Lubienski and Crane [25] report that in more recent studies using National Assessment of Educational Progress (NAEP) data, Lubienski and Lubienski [26] found that mathematics achievement in public schools was slightly higher than that in demographically similar private schools. Subsequently, in a study commissioned by the federal Department of Education, Braun et al. [7] reported similar findings regarding NAEP achievement in public and private schools. A handful of longitudinal analyses have pointed in the same direction, raising questions about assumptions that structural aspects of the private school sector necessarily lead to better learning outcomes [25,36].

Espisito [14] observes that although numerous studies have examined whether school type or competition results in improved academic performance [4,37], the results are mixed, with some studies finding improvements and other studies finding none, regardless of whether the research examined vouchers, charter schools, religious schools, comprehensive school reform, or school accountability generally. While most of these studies are observational, even the few experimental studies have yielded inconsistent findings.

Justifications for different school types include a causal assumption: a student's achievement is primarily, or at least very substantially, determined by the school, and that better or different schools would result in improved student academic achievement and fewer failing students [35]. This strong linkage of student performance to school characteristics has led to much of the current demand for school choice and different school types, including magnets. While not directly assessing whether magnet schools improve student achievement, Goldschmidt and Martinez-Fernandez [20] found in a California sample using a three level hierarchical linear model that a magnet school was a reliable indicator of the probability of passing the California High School Exit Exam, even after accounting for Students' differences. 


\section{Statement of the Problem}

Cameroon aims at achieving emergence in 2035 . Science and Technology is critical in achieving this goal and numeracy drives science and Technology. The amplified need for numeracy is a result of the demands of the technologically oriented age. Many studies have focused on literacy as numeracy cannot be achieved without literacy since it involves the reading and interpretation of symbols. Yet, one could be literate without basic numeracy skills consisting of comprehending fundamental arithmetic like addition, subtraction, multiplication, division and computation which are fundamental for measurement, geometry, probability and statistics. Unfortunately, numeracy has been given very little attention in Cameroon. While there is an observation that the standard of primary education has dropped, it is difficult to assert the validity of such an assertion without measuring final year pupils' achievement with regard to mathematics and this achievement may vary according to school type. Thus the study set out to assess final year pupils' achievements in mathematics based on school type. This is an important quality control mechanism to assess the future of science and Technology in Cameroon and which type of schools provide a more solid foundation for science and technology. Results of this study may serve as a basis for pedagogical reforms.

\subsection{Hypotheses}

- The general level of numeracy is not significantly low in primary schools in English Speaking Cameroon

- There is no significant influence of school type on the level of numeracy in primary schools in English Speaking Cameroon.

- There is no significant difference in the level of numeracy in primary schools between the South West and the North West Regions of Cameroon

\section{Methodology}

The study was a survey that involved a purposively selected sample of 727 primary six (final year) pupils, from 18 schools (a public, private and confessional school each) in six randomly selected divisions of the two English-speaking regions of Cameroon. These divisions included Fako, Meme, Ndian, Mezam, Momo, Ngoketunjia. An achievement test which is an extract of the Mathematics paper of the 2013/2014 First School Leaving Certificate (FSLC) examination was used for data collection. Thus validity and reliability of the instrument had already been established by the Ministry of Basic Education. The test was administered to class six pupils, one month prior to their graduation from primary school, to determine their attainment in numeracy. The test items required pupils to solve mathematical problems by applying the rule of BODMAS, decimals and analyze a population using descriptive statistics. Permission was obtained from Head-teachers and they were assured of the anonymity of the results. Six teachers who did not take part in the study with at least five years of experience as examiners at the FSLC were selected to mark the test.

\section{Findings}

\subsection{Hypothesis One}

The general level of numeracy is not significantly low in primary schools in English Speaking Cameroon

The data collected for the level of numeracy of primary schools pupils in English Speaking Cameroon was got through a test that was administered to the pupils. The Population t-test statistical analysis tool was used for analysis. The results are presented in Table 1.

The result of the analysis of the data collected from the test showed that the p-values for level of numeracy ( $p=0.00$ ) is lower than the significance level of 0.05 with 755 degrees of freedom. The null hypothesis is therefore rejected. This means that the general level of numeracy is significantly low in primary schools in English Speaking Cameroon. The analysis reveals that the $t$-value is negative hence significantly low $(\mathrm{t}=-32.76)$.

\subsection{Hypothesis Two}

There is no significant influence of school type on the level of numeracy in primary schools in English Speaking Cameroon.

The respondents in the sample were categorized into three groups based on the type of school they were attending. These groups were categorized as follows:

Group One: Public Schools

Group Two: Confessional Schools

Group Three: Lay Private Schools

The data collected for the level of numeracy of primary school pupils in English Speaking Cameroon was got through a test that was administered to the pupils. The statistical analysis technique used to test this hypothesis was One-Way Analysis of Variance (One Way - ANOVA). The results of the data analyses are presented in Table 2.

The result of the analysis of the data collected from the test showed that the p-values for level of numeracy $(\mathrm{p}=0.00)$ is lower than the significance level of 0.05 with 2 and 722 degrees of freedom. The null hypothesis is therefore rejected. This means that there is a significant influence of school type on the level of numeracy in primary schools in English Speaking Cameroon.

Table 1. Population t-test analysis of the general level of numeracy amongst pupils in primary schools in English Speaking Cameroon (N=725)

\begin{tabular}{cccccc}
\hline Test variables & Mean & SD & Reference Mean & t-value \\
\hline Level of Numeracy & 4.84 & 4.24 & 10 & -32.76 & 0.00 \\
\hline
\end{tabular}


Table 2. Group means and standard deviations for the three groups on test and the actual analysis of ANOVA

\begin{tabular}{|c|c|c|c|c|c|}
\hline School Type & $\mathbf{N}$ & Mean & SD & & \\
\hline Public & 323 & 4.54 & 3.74 & & \\
\hline Confessional & 206 & 3.71 & 3.20 & & \\
\hline Lay Private & 196 & 6.53 & 5.34 & & \\
\hline Total & 725 & 4.84 & 4.24 & & \\
\hline Sources of Variation & Sum of squares & df & Mean Square value & $\mathbf{F}$ & p-value \\
\hline Between Group & 848.635 & 2 & 424.318 & $25.201 *$ & 0.000 \\
\hline Within Group & 12156.752 & 722 & 16.833 & & \\
\hline Total & 13005.387 & 724 & & & \\
\hline LSD Multiple Comparisons & Mean Difference & p-value & & & \\
\hline Public - Confessional & $0.82 *$ & 0.025 & & & \\
\hline Public - Lay Private & $1.99 *$ & 0.000 & & & \\
\hline Lay Private - Confessional & $2.81^{*}$ & 0.000 & & & \\
\hline
\end{tabular}

Since school type significantly influences the level of numeracy in primary schools in English Speaking Cameroon a further pattern of the influence was explored using the Fisher's Least Significant Difference (LSD) multiple comparison analysis. The result of the analysis shows a significant difference in numeracy between public and confessional schools ( $\mathrm{p}$-value $=0.025$ ) also a significant difference between public and Lay Private schools (p-value $=0.000$ ) and between Lay Private and confessional schools ( $\mathrm{p}$-value $=0.000$ ). Comparing their means reveals that the level of numeracy for public schools (mean $=4.53$ ) is higher than the level of numeracy for confessional schools (mean= 3.71). Also the level of numeracy for lay private schools (mean=6.53) is higher than the level of numeracy for confessional schools $($ mean=3.71) and public schools (mean=4.53).

\subsection{Hypothesis Three}

There is no significant difference in the level of numeracy in primary schools between the South West and the North West Regions of Cameroon

The respondents in the sample were categorized into two groups based on the regions they were attending school.

Group 1: South West

Group 2: North West

The data collected for the level of numeracy of primary school pupils in English Speaking Cameroon was got through a test that was administered to the pupils. The statistical analysis technique used to test this hypothesis was the independent t-test. The result of the analysis is presented in Table 3.

Table 3. Independent t-test analysis of influence of region on the level of numeracy of primary school pupils in English Speaking Cameroon (N=725)

\begin{tabular}{cccccc}
\hline Region & $\mathrm{N}$ & Mean & $\mathrm{SD}$ & $\mathrm{t}$-value & $\mathrm{p}$-value \\
\hline South West & 447 & 5.54 & 4.63 & 5.72 & 0.00 \\
North West & 278 & 3.73 & 3.22 & & \\
Total & 725 & 4.84 & 4.24 & & \\
\hline
\end{tabular}

${ }^{*} \mathrm{p}<0.05, \mathrm{df}=723$; critical $\mathrm{t}=1.97$.
The result of the analysis of the data collected from the test showed that the $\mathrm{p}$-values for level of numeracy ( $\mathrm{p}=$ 0.00 ) is lower than the significance level of 0.05 with 723 degrees of freedom. The null hypothesis is therefore rejected. This means that there is a significant difference in the level of numeracy in primary schools between the South West and the North West regions of Cameroon. Given these results the mean scores for numeracy for the two regions were compared. The mean score for the South west $($ mean $=5.54)$ was found to be higher than the mean score for the North West (mean = 3.73). Therefore pupils in the South West region perform better than pupils in the North West Region in numeracy.

\section{Discussion}

Achievement in mathematics in English-speaking primary schools in Cameroon is generally low. This implies that the foundation for Science and technology required to propel Cameroon to emergence is weak. Mathematics and technology have a fruitful relationship with each other. The mathematics of connections and logical chains, for example, has contributed greatly to the design of computer hardware and programming techniques. Mathematics also contributes more generally to engineering, as in describing complex systems whose behavior can then be simulated by computer. Therefore, with a weak background in mathematics, all of these cannot be achieved. Malcom [29] cautions that mathematical achievement in a technological and global society will have a major impact on students' career aspirations, their role in society, and even their sense of personal fulfillment. Thus, the need to understand and to use mathematics and technology is fundamental to $21^{\text {st }}$ century life. Therefore, with such low achievement globalization may not be enhanced since science and technology drive globalization. Furthermore, outside the traditional spheres of science and engineering, mathematics is being called upon to analyze and solve a widening array of problems in communication, finance, manufacturing, and business. Progress in science, in all its branches, requires close involvement and strengthening of the mathematical enterprise; new science and new mathematics go hand in hand [44]. 
With regard to school type achievement in numeracy differs significantly with private schools having a better performance than public and confessional schools. Also, there is a significant difference in achievement with regard to location. Schools in the South West Region perform significantly better than those in the North West Region. This implies that schools in the South west region and private school pupils have a better and private schools foundation for science and technology than public and confessional school pupils and can make a better contribution to societal development in future. These findings are in line with those of Bifulco, Cobb, and Bell [5] who found in a lottery assignment design, evidence of improvement in academic performance by students in some magnet schools in Connecticut, with effect sizes in the Range of $0.13-0.280$ for $10^{\text {th }}$ grade mathematics and.13-.23cm for reading compared to public students. Cynthia \& Megan [10] reported similar findings. They confirmed a strong and positive relationship between quality of school facilities and student achievement in English and Mathematics. In Nigeria, it is the general opinion of people that private schools are better in terms of the availability of human resources and physical facilities and consequently students' performance, than public schools [38].

However, there are mixed findings with regard to school type and achievement in mathematics. Lubienski, Lubienski and Crane [25] report that in more recent studies using National Assessment of Educational Progress (NAEP) data, Lubienski and Lubienski [26] found that mathematics achievement in public schools was slightly higher than that in demographically similar private schools. Subsequently, in a study commissioned by the federal Department of Education, Braun et al. [7] reported similar findings regarding NAEP achievement in public and private schools. A handful of longitudinal analyses have pointed in the same direction, raising questions about assumptions that structural aspects of the private school sector necessarily lead to better learning outcomes [25,36,42].

Frederick [16] views school location as one of the major factors that influence students' academic achievement in some subject areas. Ajayi [1] asserts that school location can affect students' learning outcomes either positively or negatively. Urban environment can be conceptualized as that which has high population density, containing a high variety of beautiful common place views, whereas rural environment is characterized by low population density containing a low variety and isolated place views.

\section{Conclusion}

Mathematics achievement and numeracy in Englishspeaking primary schools in Cameroon is low. This implies a poor foundation for science and technology and higher order thinking skills. With such a situation Cameroon may not achieve its vision of becoming an emergent country in 2035. Therefore much needs to be done to increase achievement in mathematics in primary schools. Leone, Wilson, and Mulcahy, [23] propose the following pedagogical guidelines to increase achievement in mathematics: Promote student engagement and a classroom environment conducive to learning; Implement screening, diagnostic testing, and progress monitoring; Use explicit instruction by knowledgeable teachers to teach new numeracy skills and grade-appropriate mathematics concepts; Provide an environment that supports teachers, promotes educational leadership, and fosters high quality mathematic instruction and numeracy. Grouws and Cebulla [21] propose some tips that increase pupils' achievements in mathematics: The extent of the students' opportunity to learn mathematics content bears directly and decisively on student mathematics achievement; Focusing instruction on the meaningful development of important mathematical idea increases the level of students' learning. Students can learn both concepts and skills by solving problems; Giving students both an opportunity to discover and invent new knowledge and an opportunity to practice what they have learned improves student achievement; Teaching that incorporates students' intuitive solution methods can increase student learning, especially when combined with opportunities for student interaction and discussion; Using small groups of students to work on activities, problems and assignments can increase student mathematics achievement; Whole-class discussion following individual and group work improves students achievement; Teaching mathematics with a focus on number sense encourages students to become problem solvers in a wide variety of situations and to view mathematics as a discipline in which thinking is important; Long-term use of concrete materials is positively related to increases in student mathematics achievement and improved attitudes towards mathematics and using calculators in the learning of mathematics can result in increased achievement and improved student attitudes.

\section{References}

[1] Ajayi, A. (2006). The influence of school type and location on resource availability and pupils learning outcome in primary schools in Ekiti State, Nigeria. Educational Thought. Retrieved from

https://www.questia.com/library/journal/1P3-2613272731/effectsof-school-location-on-students-learning-outcomes.

[2] The Essential Skill of Numeracy. Retrieved from http://www.barrettrose.com/the-essential-skill-of-numeracy/.

[3] American Association of University Women. (2000). Tech-savvy: Educatinggirls in the new computer age (Executive Summary). Washington, DC: American Association of University Women. Retrieved, from http://www.aauw.org/research/girls_education/techsavvy.cfm.

[4] Bifulco, R.,\& Ladd, H.F.(2006).The impact of charter schools on student achievement: Evidence from North Carolina. Education Finance and Policy, 24(2), 133-147.

[5] Bifulco, R., Cobb,C.,\& Bell, C. (2009).Can Inter district Choice Boost Student Achievement? The Case of Connecticut's Inter district Magnet School Program. Educational Evaluation and Policy Analysis, 31(4), 323-345.

[6] Borgman, C. L., Abelson, H. Dirks, L., Johnson, R., Koedinger, K. R., Linn, M. C., Lynch, C. A.,Oblinger, D. G., Pea, R. D., Salen, K., Smith, M. S., \& Szalay, A. (2008). Fostering learning in the networked world: The cyber learning opportunity and challenge, A 21st Century agenda for the National Science Foundation (Report of the NSF Task Force on Cyber learning). Washington, D.C.: National Science Foundation.

[7] Braun, Henry, Frank Jenkins, and Wendy Grigg. (2006) Comparing Private Schools and Public Schools Using Hierarchical 
Linear Modeling (NCES 2006-461). Washington, DC:National Center for Education Statistics.

[8] Burns, J (2012). Poor numeracy 'blights the economy and ruins lives'. Education Reporter, BBC News. Retrieved from http://www.bbc.com/news/education -17224600.

[9] Cosgrove, J., Shiel, G., Sofroniou, N., Zastrutzki, S., \& Shortt, F. (2005). Education for life: The achievements of 15-year-olds in Ireland in the second cycle of PISA. Dublin: Educational Research Centre.

[10] Cynthia, U., \& Megan, T. (2008). The walls speak: the interplay of quality facilities, school climate, and student achievement. Journal of Educational Administration, 46 (1), 55-73.

[11] Daugherty, J.L;. Reese, G.C and Merrill, C (n.d). Trajectories of Mathematics and Technology Education Pointing To Engineering Design. The Journal of Technology Studies. Retrieved from https://scholar.lib.vt.edu/ejournals/JOTS/v36/v36n1/pdf/daugherty .pdf.

[12] Department of Education and Early Childhood Development, (2009). Numeracy in practice: teaching, learning and using mathematics. Retrieved from

https://www.eduweb.vic.gov.au/edulibrary/public/publ/research/n ws/nume racy_in_practi ce_paper_no_18.pdf.

[13] Department of Education and Children's Services, (2013). Numeracy Strategy. Retrieved from http://www.cne-siar.gov.uk/education/policiesprocedures/ documents/Numeracy\%20Strategy\% 20Nov\%202013.pdf.

[14] Esposito, C.L. (2010). School Type and Mathematics Achievement: A Comparison of Magnet and Public Secondary Schools Using the Educational Longitudinal Study of 2002 Data Set. Doctoral Dissertation, University of Connecticut, Storrs, CT.

[15] Esposito, C., \& Cobb, C. (2008). Estimating the School-Level Effects of Choice on Academic Achievement in Connecticut's Magnet, Technical and Charter Schools. Paper presented at the American Education Association Annual Meeting.

[16] Fredrick, E.O. (2011). Influence of sex and location on students achievement in agricultural science. African Journal of Science, Technology and Mathematics Education, 1 (11) 96.

[17] Foghlam, A (2015). Numeracy and Mathematics: Assessing progress and achievement Framework. Education Scotland Retrived from

https://highlandnumeracyblog.files.wordpress.com/2015/01/assess ing-progress-and-achievement- framework-1.pdf.

[18] Fox, J. L. (2007). 21st Century Children, Numeracy and Technology: An analysis of Peer- reviewed Literature. In Woo, Jeong-Ho and Park, Kyo-Sik and Lew, Hee-Chan and Seo, DongYeop, Eds. Proceedings 31st annual Meeting of The International Group for the Psychology of Mathematics Education 2, 241-248, Seoul, Korea.

[19] Fullarton, S., Walker, M., Ainley, J. \& Hillman, K. (2003). Patterns of participation in Year 12. (LSAY Research Report No. 33). Melbourne: ACER

[20] Goldschmidt, P., \&Martinez-Fernandez, J.F. (2004). The Relationship between School Quality and the Probability of Passing Standards- Based High-Stakes Performance Assessments. CSE Technical Report 644. Los Angeles, CA: Center for Research on Evaluation Standards And Student Testing, UCLA Center for the Study of Evaluation.

[21] Grouws, D. A. - Cebulla, K. J. (2000). Improving Student Achievement in Mathematics Part 1: Research Findings. ERIC Digest. Retrieved from

http://www.ericdigests.org/2003- 1/math2.htm.

[22] Irish National Teachers' Organization (2013). Numeracy in the primary school. Retrieved from

https://www.into.ie/ROI/NewsEvents/Conferences/EducationCons ultativeConference/EducationConsultativeConference2013/Ed_Co nf_20.

[23] Leone, P; Wilson, M and Mulcahy, C. (2010). The National Evaluation and Technical Assistance Center for the Education of Children and Youth Who Are Neglected, Delinquent, or At Risk. Retrieved from

http://www.neglecteddelinquent.org/sites/default/files/docs/numer acy_gui de_201008.pdf.

[24] Lamb, S. and Fullarton, S (2001). Classroom And School Factors Affecting Mathematics Achievement: a Comparative Study of the US and Australia Using TIMSS. Retrieved from http://research.acer.edu.au/timss_mo nographs/10.
[25] Lubienski, S.T., Lubienski, C and Crane, C.C (2008). Achievement differences and school type: The role of school climate, teacher certification, and instruction. Retrieved from http://www.classsizematters.org/wpcontent/uploads/2011/04/Lubienski_2008.pdf.

[26] Lubienski, Sarah Theule, and Christopher Lubienski. (2006) "School Sector and Academic Achievement: A Multi Level Analysis of NAEP Mathematics Data. American Educational Research Journal,43 (4): 651-98.

[27] Lubienski, Christopher, Corinna C. Crane, and Sarah T. Lubienski. (2008). "What DoWe Know about School Effectiveness? Academic Gains in Public and PrivateSchools." Phi Delta Kappan89 (9): 689-95.

[28] McMillan, J. \& Marks, G.N. (2003). School leavers in Australia: Profile and pathways. (LSAY Research Report No. 31). Melbourne: ACER.

[29] Malcom, S. (1999). Making sense of the world. In, Dialogue on early childhood science, mathematics, and technology education, (pp.8-13). Washington: American Association for the Advancement of Science.

[30] McAleavy, T (2012). Exploring different pproaches to teaching primary maths. Retrieved from https://www.theguardian.com/teachernetwork/2012/jul/20/primary- maths- programme.

[31] National Commission on Mathematics and Science Teaching for the 21st Century. (2000). Before it's too late: A report to the Nation from the National Commission on Mathematics and Science Teaching for the 21st Century. Washington, DC: U.S. Department of Education.

[32] National Council of Teachers of Mathematics. (2000). Principles and standards for school mathematics. Reston, VA: National Council of Teachers of Mathematics.

[33] National Mathematics Advisory Panel. (2008). Foundations for success: The final report of the National Mathematics Advisory Panel.Jessup, MD: U.S. Department of Education.

[34] O’Donoghue, J (2002). Numeracy and Mathematics. Irish Math. Soc. Bulletin, 48, 47-55

[35] Raudenbush, S. W. 2004. Schooling, Statistics, and Poverty: Can We Measure School Improvement? Educational Testing Service, Princeton, NJ, USA.

[36] Reardon, S. F., J. E. Cheadle, and J. P. Robinson. (2008). "The Effect of Catholic Schooling on Math and Reading Development in Kindergarten through Fifth Grade.” Paper presented at the annual meeting of the Society for Research on Educational Effectiveness, March 2-4, Crystal City, VA.

[37] Rouse, C.E., \& Barrows, L. (2008). Do Education Vouchers Improve Student Learning and Public School Achievement? National Center for the Study of Privatization in Education. Retrieved from http://www.ncspe.org/publications files/OP163.pdf

[38] Sabitu, A.O., Babatunde, E.G and Oluwole, A.F. (2012). School types, facilities and academic performance of students in senior secondary schools in Ondo State, Nigeria. International Education Studies, 5, (3), 1-5.

[39] Science for All Americans, $(1989,1990)$. The Nature of Mathematics. Retrieved from

http://www.project2061.org/publications/sfaa/online/chap2.htm?tx tRef=https\%3A\%2F\%2Fwww\%2Egoogle\%2Ecm\%2F\&txtURIOl $\mathrm{d}=\% 2$ Ftools\%2Fsfaaol\%2Fc hap2\%2Ehtm.

[40] Sheil, G., Moran, G., Cosgrove, J. and Perkins R. (2010) A Summary of the performance of Students in Ireland on the PISA 2009 Test of Mathematical Literacy and a Comparison with Performances in 2003 Dublin: Educational Research Centre.

[41] Steen, L. A. (2001). Mathematics and numeracy: Two literacies, one language. The Mathematics Educator, 6(1), 1016.

[42] Taningco, M. T. (2006). "Assessing the Effects of Parental Decisions about School Type and Involvement on Early Elementary Education.” PhD diss., Pardee Rand Graduate School, http://www.rand.org/pubs/rgs_dissert ations/RGSD205/.

[43] The Mathematical Sciences in 2025 (2013) National Research Council of the National Academies. Washington. National Academies Press from https://www.nap.edu/read/15269/c hapter/5\#64

[44] Wright, M and Chorin, A. (1999) mathematics and Science. National Science Foundation. Retrieved from https://nsf.gov/pubs/2000/mps0001/mps0001.pdf. 